\title{
カビ発醅サラミソーセージの熟成・乾燥期間中に 㧍ける風味関連物質の変化
}

\author{
沼田正寛・富家崇弘・水谷祥彦 \\ 橋本小由利・山田浩之・中村豊郎 \\ 伊藤八厶株式会社中央研究所，東京都目黑区 153
}

(1987. 8. 16 受付)

\begin{abstract}
要 約 カビ発醉サラミンーセージの熟成風味発現機構の解明の観点から，熟成・乾燥期間中の風 味関連物質の生成に及ぼす系状菌の影響について調べた，糸状菌としてPenicillium miczynskii を 用い, Lactobacillus plantarum により内部発醳をコントロールしたサラミンーセージ（M.F.S.S.), L. plantarum だけを用いたサラミンーセージ（F.S.S.）およびP. miczynshii およびL. plantarum を用いないサラミンーセージ（S.S.）の3 種類のサラミンーセージを作り，これらについてそれぞれ表 層部，中心部における各種成分の経時变化老比較した結果，次のことが明らかとなった（1)熟成・乾 燥 0 日目の試料中に最も多く存在する遊離アミノ酸は，Tau, Gln, Ala, Gly の順であった，その後，F. S.S. および M.F.S.S. では熟成・乾燥の進行に伴い全遊離アミ/酸量は增加の一途であったが, S.S. では20日目に最高に達した後，減少傾向を示した，しかし，いずれの試験区においても顕著な增加を 示した遊離アミノ酸は同じで, Glu, Leu, Lys, Ala であった. (2)アンモ二ア含量の增减傾向には試 験区間に差は認められず. いずれる経時的に增加して，20日目に最高に達した後，減少傾向を示した。(3)遊 離アミノ酸，アンモ二丁含量とも表層部に比べ中心部の方が多い傾向であった（4)ぺプチドは全武験 区上も分子量 800 程度に主ピークが認められるだけで，経時的に变化することはなかった（5)遊離脂 肪酸は M.F.S.S. の表層部で顕著な増加を示した。特に熟成・乾燥初期に著しく, 10 日目で 3.5 倍に 達した．以後 20 日目まで漸増したが，その後の変化は認められなかった．各遊離脂肪酸の中では $\mathrm{C}_{16: 0}$ および $\mathrm{C}_{18: 1}$ の增加が顕著でおった，これに対して，それ以外の試験区での増加はゆるやかであり，40日 目に0日目の約 2 倍に達したに過ぎない，これらの試験区間においては遊離脂肪酸の增加に量的な差は 認められなかった，また，遊離脂肪酸組成はいずれの試験区でも顕著な差は認められなかった。
\end{abstract}

日畜会報，59（2）：136-145，1988

カビ発酵サラミンーセージ (mold-fermented salami sausage; M.F.S.S.) の秇成風味発現機構の解明の一 環として，著者らはまず M.F.S.S.の表層部からPenicillium miczynskii を分離し，同菌が製造期間をとお して常に優勢菌種であることを報告したり。そしてこの 分離株を用いた M.F.S.S.の製造モデル試験により， 熟成風味発現に及ぼす同菌の影響について検討した結果, 熟成風味の発現にはンーセージ表層部に発育する糸状菌 の存在が不可欠な要因であること，その糸状菌しして $P$. miczynskii が適した性状を有していること㧍よびP. miczynskii の発音に従ってある一定期間までは熟成風 味羊增強されるが，それ以降は風味の強さに変化が生じ ないことを明らかにしだ，しかし，まだその熟成風昧
を付与する原因物兵を明らかにするまでには至らなかっ た.

ところで表層部に系状菌を着生させないで熟成乾燥を 行なう食肉製品では，カテプシンなどの存在のほか，原 料肉中の微生物によって産生されるプロテアーゼまたは リパーゼなどの作用により蓄積量が增大する遊離アミ， 酸、ペプチド，核酸関連物質，有機酸または遊離脂肪酸 などの物質またはその分解物が就成風味に関与すること が知られている

そこでわれわれは，この M.F.S.S.における熟成風 味発現機構を明らかにするため，これらの風味関連物質 について，前報2)で実施した製造モデル試験の試料を用 いてそれらの消長を測定した結果，新たな知見を得たの 
でここに報告する．

\section{材料および方法}

\section{1. 実験材料}

供試のサラミンーセージは，スターターカルチャーと して Lactobacillus plantarum TF-1 株を用いて内 部発醉をコントロールし，同時にP. miczynskii を表 層部に着生させたサラミッーセージ（M.F.S.S.），L. plantarum $\mathrm{TF}-1$ 株だけを接種したサラミンーセージ (fermented salami sausage； F.S.S.) および無接種 のサラミンーセージ (S.S.) の 3 種類であり，その製造 方法、スターターカルチャ一の調製方法および接種方法 は前報2記載のとおりである。

\section{2. 試料の調製}

熟成・乾燥期間中の 3 種類のサラミンーセージについ て，経時的に各 5 本ずつをサンプリングした．熟成・乾 燥 0 日目はソーセージ全体を均質試料とし，それ以外は 表面より厚さ $5 \mathrm{~mm}$ 以内にわたって切り取った表層部 と，中心から半径 $1 \mathrm{~cm}$ までを切り取った中心部とに分 けて試料とした，各試料は 5 本分まとめて真空包装し， 全試料のサンプリングが終了するまで $-20^{\circ} \mathrm{C}$ 以下に凍 結保管した。

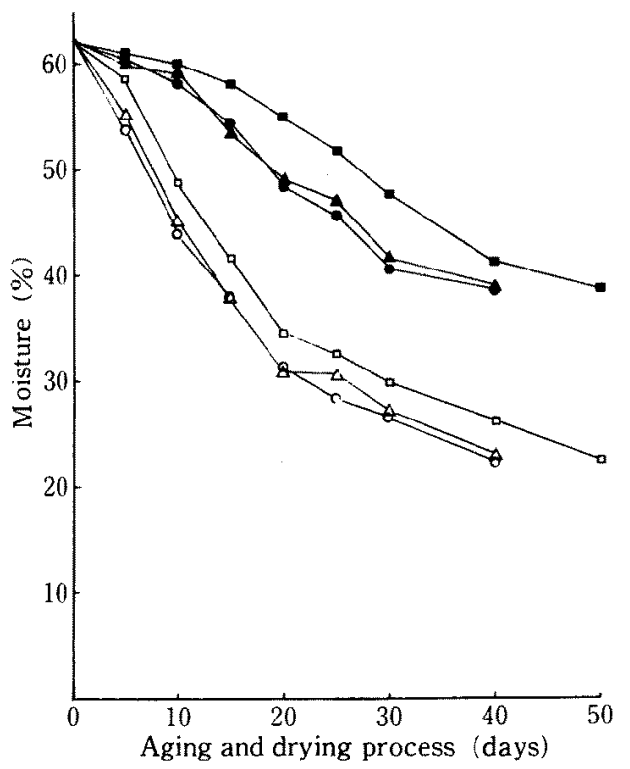

Fig. 1. Changes in moisture content during aging and drying process $O$ : surface of S.S., - : internal part of S.S., $\triangle$ : surface of F.S.S., A : internal part of F.S.S., $\square$ : surface of M.F.S.S. and : internal part of M.F.S.S.

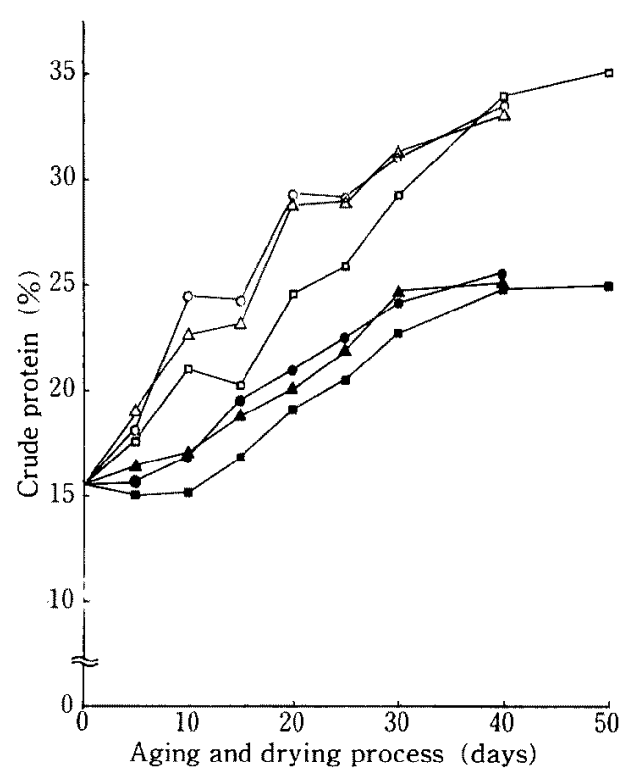

Fig. 2. Changes in crude protein content during aging and drying process $O$ : surface of S.S.; : internal part of S.S., $\triangle$ : surface of F.S.S., $\boldsymbol{\Lambda}$ : internal part of F.S.S., $\square$ : surface of M.F.S.S. and $\mathbf{\square}$ : internal part of M.F.S.S.

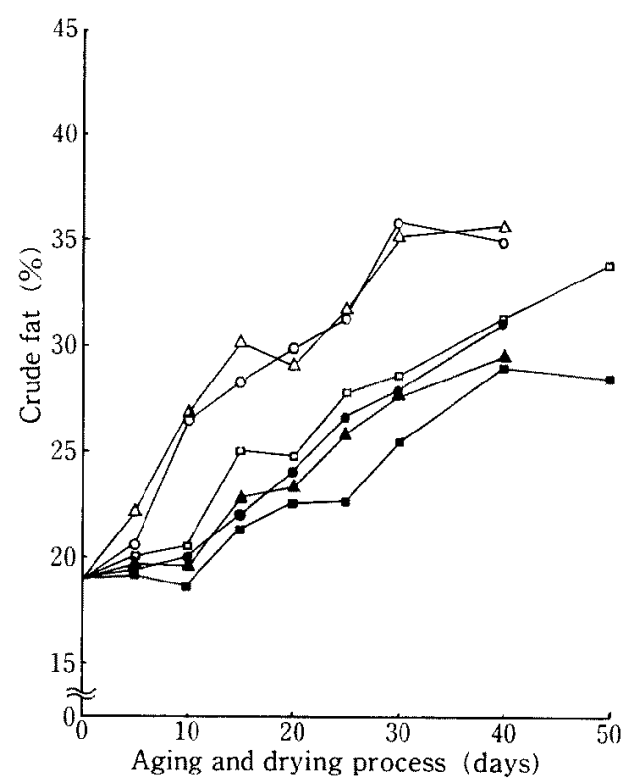

Fig. 3. Changes in crude fat content during aging and drying process $O$ : surface of S.S., - : internal part of S.S., $\triangle$ :surface of F.S.S., $\Delta$ : internal part of F.S.S., $\square$ : surface of M.F.S.S. and $\mathbf{U}$ : internal part of M.F.S.S. 
沼田・畐家・水谷・橋本・山田・中村

3. 分析今法

3.1 一般分析 水分は JAS 水分測定法7)，粗たんぱ

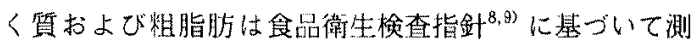
定した。

3.2 逝離了ミ/酸 沖谷らの方法 ${ }^{10)}$ に従い, 試料に 1.6 倍量の水之0.1倍量の $27 \mathrm{mM} ア シ ゙$ 化ナトリウム溶 液老加えてホモジナイズ後，終浸度 $5 \%$ になるように卜 リクロロ酶酸溶液を加えて除たんぱくした。この酸可溶 性画分を水酸化ナトリゥムで $\mathrm{pH} 2.2$ に調整後，日本分 光製 800 シリーズ高速液体クロマトグラフィーを用い同 定, 定量した。

3.3 アンモニア アンモニアの定量は CONWAY の 微量拡散行析法 ${ }^{11)}$ に従った。

3.4 ペプチド 試料に 1.7 倍量の水を加えてホモジ ナイズ後, 終濃度 $5 \%$ になる上うにトリク口酷酸溶液
を加えて除たんぱくしたこの酸可溶性画分をジェチル エーテルで脱脂後，高速液体クロマトグラフィーを用い， ペプチドの分子睤分布を湘定した，高速液体クロマトグ ラフィーの操作条件は以下のとおりとした，カラム；東 洋曹達製 TSK gel G $3000 \mathrm{PW} \times \mathrm{L}$ ，移動相; トリフ ルオロ酢酸：アセトニトリル：水 $(0.1: 45: 54.9)$, 流 速; $0.5 \mathrm{ml} / \mathrm{min}$. 検出波長; $210 \mathrm{~nm}$.

3.5 遊離脂肪酸 試料加ら FOLCH らの方法 ${ }^{12}$ に準 じて粗総脂質を抽出した，更に MCCARTHY らの方法 ${ }^{132}$ により遊離脂肪酸を抽出し，その脂肪酸を三フッ化ホウ 菜メタノール法年でメチルエステル化したのち，ガス クロマトグラフィーで分析した．ガスクロマトグラフィ 一の操作条件は以下のとおりとした。装置；島津製作所 製 GC-9 A 型，充境剂; $5 \%$ Advance DS Chromosorb W (80-100 mesh), カラム ; ガラスカラム (3

Table 1. Changes in free amino acids ${ }^{\mathrm{a}}$ and ammonia in S.S. at five stages during aging and drying process ( $\mathrm{mg} / \mathrm{g}$ protein)

\begin{tabular}{|c|c|c|c|c|c|c|c|c|c|}
\hline \multirow[b]{2}{*}{ Variables } & \multicolumn{5}{|c|}{$\begin{array}{l}\text { Surface } \\
\text { Stage of aging and drying (days) }\end{array}$} & \multicolumn{4}{|c|}{$\begin{array}{l}\text { Internal part } \\
\text { Stage of aging and drying (days) }\end{array}$} \\
\hline & 0 & 10 & 20 & 30 & 40 & 10 & 20 & 30 & 40 \\
\hline Tau & 4.64 & 4.44 & 4.47 & 3.09 & 2.98 & 5.26 & 8.34 & 5.79 & 5.39 \\
\hline Asp & 0 & 0.64 & 0.84 & 0.80 & 0.83 & 0.52 & 1.41 & 1.20 & 1.01 \\
\hline Thr & 0.17 & 0.15 & 0.99 & 0.97 & 1.01 & 1.00 & 1.58 & 1.74 & 1.88 \\
\hline Ser & 0.27 & 1.12 & 1.47 & 1.34 & 1.52 & 1.43 & 2.24 & 2.45 & 2.27 \\
\hline Asn & 0 & 0.45 & 0.63 & 0.57 & 0.66 & 0.60 & 0.74 & 0.93 & 0.44 \\
\hline Glu & 0.52 & 2.06 & 2.36 & 1.95 & 2.51 & 2.38 & 4.28 & 4.03 & 4.25 \\
\hline Gin & 4.60 & 4.30 & 4.83 & 3.42 & 3.08 & 6.32 & 7.54 & 4.03 & 3.02 \\
\hline Gly & 0.55 & 1.09 & 1.29 & 0.92 & 1.25 & 1.31 & 2.06 & 2.06 & 1.90 \\
\hline Ala & 1.55 & 2.93 & 3.60 & 3.24 & 3.13 & 3.88 & 5.51 & 5.97 & 5.47 \\
\hline $\mathrm{Cit}^{\mathrm{b}}$ & 0 & 0 & 0 & 0.23 & 0.82 & 0 & 0 & 0 & 0.21 \\
\hline $\mathrm{Val}$ & 0.15 & 1.12 & 1.56 & 1.45 & 1.43 & 1.22 & 2.20 & 2.68 & 2.13 \\
\hline Met & 0 & 0.45 & 0.77 & 0.98 & 1.01 & 0.71 & 0.90 & 1.15 & 1.21 \\
\hline Ileu & 0.13 & 1.09 & 1.31 & 1.32 & 1.52 & 1.34 & 1.51 & 2.84 & 2.32 \\
\hline Leu & 0.30 & 1.65 & 2.62 & 2.36 & 2.33 & 2.74 & 3.19 & 3.81 & 4.01 \\
\hline Tyr & 0.12 & 0.38 & 0.55 & 0.52 & 0.48 & 0.45 & 0.60 & 0.54 & 0.21 \\
\hline Phe & 0.09 & 0.92 & 1.47 & 1.22 & 1.21 & 1.50 & 1.73 & 1.79 & 1.55 \\
\hline Orn ${ }^{c}$ & 0 & 0.88 & 1.06 & 0.49 & 0.63 & 0.91 & 1.25 & 1.12 & 1.08 \\
\hline Lys & 0.36 & 1.77 & 2.52 & 2.00 & 2.00 & 2.50 & 3.12 & 3.94 & 3.99 \\
\hline His & 0 & 0.43 & 0.62 & 0.30 & 0.41 & 0.61 & 0.67 & 0.78 & 0.50 \\
\hline Arg & 0.17 & 0 & 0 & 0.22 & 0.20 & 0 & 0 & 0 & 0 \\
\hline Pro & 0.22 & 0.76 & 0.67 & 0 & 0.33 & 1.04 & 1.27 & 1.72 & 1.12 \\
\hline Total & 13.84 & 26.63 & 33.63 & 27.39 & 29.34 & 35.72 & 50.14 & 48.57 & 43.96 \\
\hline Ammonia & 0.55 & 1.18 & 1.46 & 1.37 & 1.27 & 1.95 & 2.24 & 1.97 & 1.99 \\
\hline
\end{tabular}


$\mathrm{mmID} \times 3 \mathrm{~m})$, 力ラム温度 $; 200^{\circ} \mathrm{C}$ ，キャリヤーガス； $\mathrm{N}_{2}(40 \mathrm{ml} / \mathrm{min})$, 検出器; FID $\left(220^{\circ} \mathrm{C}\right)$.

\section{結果および考察}

1. 一般分析

図 1-3に S.S., F.S.S. および M.F.S.S. の水帉, 粗たんぱく質，粗脂肪の組成の経時的变化を，表䙓部お よび中心部とに区別して示した，S.S.とF.S.S.間に はいずれの值についても差は認められなかった，一方，M. F.S.S.ではこれらの值と比較して5日一10日の遅延が 認められ，その差は経時的に大きくなる傾向であった。 これは M.F.S.S. では水分の蒸発速度がP. miczynskii の発育により緩和されることに㴆因すると推定される、

2. 遊離了ミ/酸

遊離アミノ酸量の測定結果を表 1 - 3 k示した。熟成
・乾燥 0 日目の試料中に多く存在する遊颜アミノ酸は Tau, Gln, Ala, Gly の順であった。これは供試部位 は異なるが，肉中に多く存在する遊離アミ，酸として， EWAN ら ${ }^{15)}$ が市販の豚ロース肉で定童した Gln, Ala， Gly, Glu, Bowers ${ }^{16)}$ の Ala, Ser, Tau, Glu さらに LAKRIT2 ら ${ }^{17}$ の豚バラ肉での Ala, Gly, Glu の結果 と比輟的に類似していた。

その後，熟成・乾燥の進行に伴い表層部，中心部とも に全遊離アミ，酸量は增加したが，S.S. 区と F.S.S. および M.F.S.S. 区間では增加傾向に差が瑟められた。 前者ではその増加が 20 日目でピークに達したのに対し て，後者では乾燥終了日まで経時的な堌加を示した，し かし各遊離アミノ酸の中で顕藷な増加を示したのは，い ずれの場合であ Glu, Leu, Lys, Ala であった. 一方, Tau は S.S. 表層部および M.F.S.S. で, G.lnは M.F.

Table 2. Changes in free amino acids ${ }^{a}$ and ammonia in F.S.S. at five stages during aging and drying process ( $\mathrm{mg} / \mathrm{g}$ protein)

\begin{tabular}{|c|c|c|c|c|c|c|c|c|c|}
\hline \multirow[b]{2}{*}{ Variables } & \multicolumn{5}{|c|}{$\begin{array}{l}\text { Surface } \\
\text { Stage of aging and drying (days) }\end{array}$} & \multicolumn{4}{|c|}{$\begin{array}{l}\text { Internal part } \\
\text { Stage of aging and drying (days) }\end{array}$} \\
\hline & 0 & 10 & 20 & 30 & 40 & 10 & 20 & 30 & 40 \\
\hline Tau & 4.64 & 4.86 & 3.55 & 5.11 & 5.02 & 6.08 & 6.58 & 6.92 & 6.88 \\
\hline Asp & 0 & 0.20 & 0.29 & 0 & 0 & 0.30 & 0.26 & 0 & 0.76 \\
\hline Thr & 0.17 & 0.34 & 0.50 & 0.57 & 0.22 & 0.41 & 0.48 & 0.73 & 1.28 \\
\hline Ser & 0.27 & 0.84 & 1.10 & 1.12 & 1.21 & 0.93 & 1.10 & 1.60 & 1.85 \\
\hline Asn & 0 & 0.62 & 0.27 & 0 & 0.33 & 0.54 & 0.67 & 0.76 & 1.84 \\
\hline Glu & 0.52 & 2.20 & 2.90 & 2.63 & 3.12 & 2.36 & 2.71 & 3.46 & 4.40 \\
\hline Gln & 4.60 & 2.08 & 2.28 & 2.97 & 2.71 & 2.16 & 2.17 & 3.07 & 2.07 \\
\hline Gly & 0.55 & 1.15 & 1.06 & 1.21 & 1.49 . & 1.44 & 1.63 & 1.72 & 2.01 \\
\hline Ala & 1.55 & 2.91 & 3.96 & 3.45 & 3.88 & 3.68 & 4.16 & 4.29 & 4.52 \\
\hline $\mathrm{Cit}^{\mathrm{b}}$ & 0 & 0 & 0 & 0 & 0 & 0 & 0 & 0 & 0.35 \\
\hline $\mathrm{Val}$ & 0.15 & 0.98 & 1.28 & 1.91 & 1.88 & 1.15 & 1.34 & 1.61 & 2.10 \\
\hline Met & 0 & 0.63 & 0.94 & 0.40 & 0.45 & 0.74 & 0.90 & 0.84 & 1.05 \\
\hline Ileu & 0.13 & 0 & 0 & 1.07 & 1.15 & 0 & 0 & 1.54 & 1.91 \\
\hline Leu & 0.30 & 2.27 & 3.12 & 2.61 & 3.01 & 2.57 & 2.77 & 3.24 & 4.01 \\
\hline Tyr & 0.12 & 0.89 & 1.08 & 0.76 & 0.45 & 1.02 & 0.92 & 0.93 & 0.82 \\
\hline Phe & 0.09 & 1.24 & 1.25 & 1.15 & 0.98 & 1.33 & 1.33 & 1.31 & 1.45 \\
\hline Orn ${ }^{c}$ & 0 & 0 & 0 & 0 & 0 & 0 & 0 & 0 & 0.82 \\
\hline Lys & 0.36 & 1.58 & 2.21 & 2.20 & 2.50 & 1.85 & 2.05 & 2.19 & 3.92 \\
\hline His & 0 & 0.38 & 0.48 & 0 & 0.33 & 0.33 & 0.38 & 0 & 0.41 \\
\hline Arg & 0.17 & 1.09 & 0.68 & 0 & 0.30 & 1.15 & 1.37 & 0 & 0.29 \\
\hline Pro & 0.22 & 0.50 & 0.88 & 0.74 & 1.01 & 0.78 & 0.88 & 0.77 & 1.02 \\
\hline Total & 13.84 & 24.76 & 27.83 & 27.90 & 30.04 & 28.82 & 31.70 & 34.98 & 43.76 \\
\hline Ammonia & 0.55 & 0.74 & 1.02 & 0.98 & 0.96 & 1.69 & 1.84 & 1.61 & 1.73 \\
\hline
\end{tabular}

"Shorthand notation

${ }^{b}$ Citrulline

'Ornithine 
S.S. 中心部を除くすべての試験区で減少傾向を示した. P. miczynskii の影響として, M.F.S.S. の表層部の 特異的な現象は，熟成・乾燥初期での Tau 拈よび Gln の著しい减少であるが，それ以外は他の試験区と比較し て顕著な差はなかった。

DIERICK ら゙はドラインーセージで, MELO ら5゙ はカ ントリースタイルハムで熟成中にそれぞれ Ala, Leu, Val, Thr, Gly およよひ Ala, Glu, Leu, Lys が增加す ることを明らかにしているが，本報告における遊離了ミ ，酸の経時的変化はカビ発酵を伴わない MELO ら5)の 結果と一致していた。 また DIERICK ら"4 は乾燥の比較 的早い時期に His, Tyr，Ornの消失およびこれらから の生成物としてヒスタミン，チラシン，プトレシンの 10 倍以上の增加を報告しているか，本報告ではこれらの遊 離アミノ酸の顕著な減少は認められなかった。
次に遊離アミノ酸量の経時的变化を表層部および中心 部に分けて比较してみると，その量はいずれにおいてる 中心部の方が大きい值を示した。このことは図1ー3で 明らかなように，中心部と比較してより乾燥状態にある 表層部は食盐漲度が上异し，このためカテプシン活性が 低下したことが一因 ${ }^{18,19)}$ と考えられた。

3. アンモニア

アンモニアの測定結果は表 1-3に併記した. S.S., F.S.S.おょび M.F.S.S. 区間には経時的な増減傾向に 差は認められず、いずれも20日目に最大に達した後， わずかに減少傾向を示した．その蓄積量は総じて S.S. が他の試験区に比べて大きい值を示した．また，サンプ リング部位による差では常に中心部の方が大きい值を示 し、これは遊離アミノ酸量の結果と同じであった。

4. ペプチド

Table 3. Changes in free amino acids ${ }^{a}$ and ammonia in M.F.S.S. at six stages during aging and drying process $(\mathrm{mg} / \mathrm{g}$ protein)

\begin{tabular}{|c|c|c|c|c|c|c|c|c|c|c|c|}
\hline \multirow[b]{2}{*}{ Variables } & \multicolumn{6}{|c|}{$\begin{array}{l}\text { Surface } \\
\text { Stage of aging and drying (days) }\end{array}$} & \multicolumn{5}{|c|}{$\begin{array}{l}\text { Internal part } \\
\text { Stage of aging and drying (days) }\end{array}$} \\
\hline & 0 & 10 & 20 & 30 & 40 & 50 & 10 & 20 & 30 & 40 & 50 \\
\hline $\mathrm{Tau}$ & 4.64 & 1.92 & 2.09 & 1.36 & 1.32 & 1.87 & 3.55 & 3.92 & 2.46 & 3.49 & 3.63 \\
\hline Asp & 0 & 0.19 & 0.36 & 0.24 & 0.42 & 0.61 & 0.22 & 0.35 & 0.45 & 0.78 & 0.87 \\
\hline Thr & 0.17 & 0.24 & 0.37 & 0.39 & 0.58 & 0.81 & 0.33 & 0.44 & 0.72 & 1.22 & 1.22 \\
\hline Ser & 0.27 & 0.46 & 0.36 & 0.64 & 0.92 & 1.28 & 0.81 & 1.02 & 1.27 & 2.12 & 2.11 \\
\hline Asn & 0 & 0 & 0 & 0.61 & 0 & 0.51 & 0 & 0 & 0.50 & 1.00 & 0 \\
\hline Glu & 0.52 & 1.38 & 2.25 & 2.38 & 2.41 & 3.62 & 2.01 & 2.61 & 3.46 & 5.56 & 5.74 \\
\hline Gln & 4.60 & 1.62 & 1.59 & 0.84 & 2.09 & 2.34 & 3.20 & 2.90 & 1.74 & 5.30 & 4.91 \\
\hline Gly & 0.55 & 0.43 & 0.48 & 0.47 & 0.69 & 0.96 & 0.80 & 0.97 & 1.06 & 1.71 & 1.79 \\
\hline Ala & 1.55 & 1.12 & 1.31 & 1.18 & 1.68 & 2.56 & 1.97 & 2.51 & 2.72 & 4.14 & 4.16 \\
\hline $\mathrm{Cit}^{\mathrm{b}}$ & 0 & 0 & 0.21 & 0 & 0.41 & 0.70 & 0 & 0.42 & 0.52 & 0.99 & 0.65 \\
\hline Val & 0.15 & 0.65 & 0.99 & 0.80 & 1.15 & 1.80 & 1.13 & 1.44 & 1.58 & 2.63 & 2.61 \\
\hline Met & 0 & 0 & 0.48 & 0.48 & 0.58 & 0.86 & 0.48 & 0 & 0.85 & 1.09 & 1.05 \\
\hline Ileu & 0.13 & 0.61 & 1.60 & 1.93 & 2.02 & 2.47 & 1.46 & 2.22 & 2.62 & 2.18 & 2.10 \\
\hline Leu & 0.30 & 1.20 & 1.72 & 1.69 & 1.91 & 2.88 & 2.05 & 0.58 & 2.56 & 3.86 & 3.88 \\
\hline Tyr & 0.12 & 0.18 & 0.38 & 0.97 & 0.48 & 0.97 & 0.51 & 0 & 0.82 & 0.88 & 0.97 \\
\hline Phe & 0.09 & 0.72 & 0.95 & 1.18 & 1.23 & 1.81 & 1.22 & 1.55 & 1.43 & 2.07 & 2.17 \\
\hline Orn ${ }^{c}$ & 0 & 0 & 0.39 & 0.43 & 0.26 & 0.65 & 0 & 0.69 & 0.63 & 0.59 & 0.90 \\
\hline Lys & 0.36 & 0.62 & 1.67 & 1.77 & 1.67 & 2.83 & 1.80 & 2.22 & 2.66 & 4.07 & 4.39 \\
\hline $\mathrm{His}$ & 0 & 0.15 & 0.48 & 0.47 & 0.45 & 0.73 & 0.43 & 0.53 & 0.72 & 1.04 & 1.02 \\
\hline Arg & 0.17 & 0 & 0.22 & 0 & 0 & 0.71 & 0.81 & 0.30 & 0.40 & 0.95 & 0.72 \\
\hline Pro & 0.22 & 0.47 & 0.77 & 0.88 & 0.73 & 1.15 & 0.64 & 0.89 & 1.00 & 1.76 & 1.84 \\
\hline Total & 13.84 & 11.96 & 18.67 & 18.71 & 21.00 & 32.12 & 23.42 & 25.56 & 30.17 & 47.43 & 46.73 \\
\hline Ammonia & 0.55 & 0.65 & 1.09 & 0.83 & 0.65 & 0.65 & 1.16 & 2.28 & 1.63 & 1.43 & 1.58 \\
\hline
\end{tabular}

a Shorthand notation

${ }^{\mathrm{b}}$ Citrulline

${ }^{c}$ Ornithine 
Table 4. Molecular weights of standard proteins and peptides

\begin{tabular}{lc}
\hline Standard sample & Molecular weight \\
\hline Cytachrome & 12,500 \\
Aprotinin & 6,511 \\
Insulin & 5,800 \\
Insulin B-chain & 3,496 \\
Bacitracin & 1,420 \\
Glutathione & 307 \\
\hline
\end{tabular}

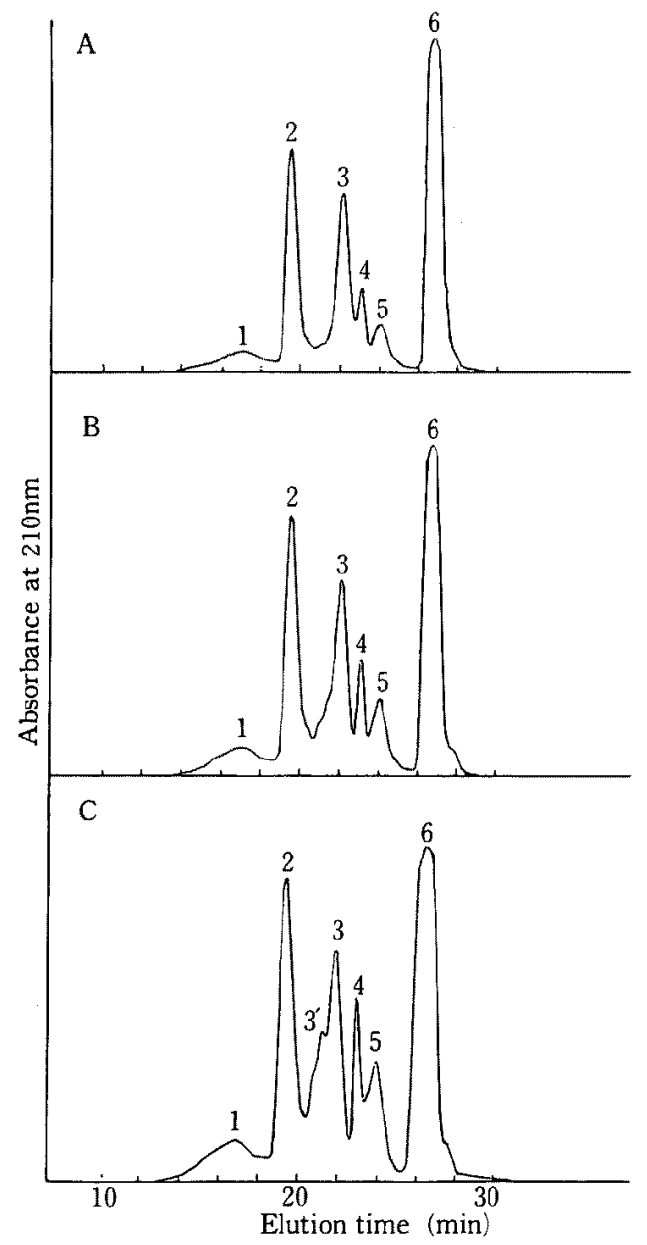

Fig. 4. HPLC patterns of the extracts of the surface of M.F.S.S. A; 0th day of aging and drying process, $B ; 20$ th day of aging and drying process, $C$; 40th day of aging and drying process.

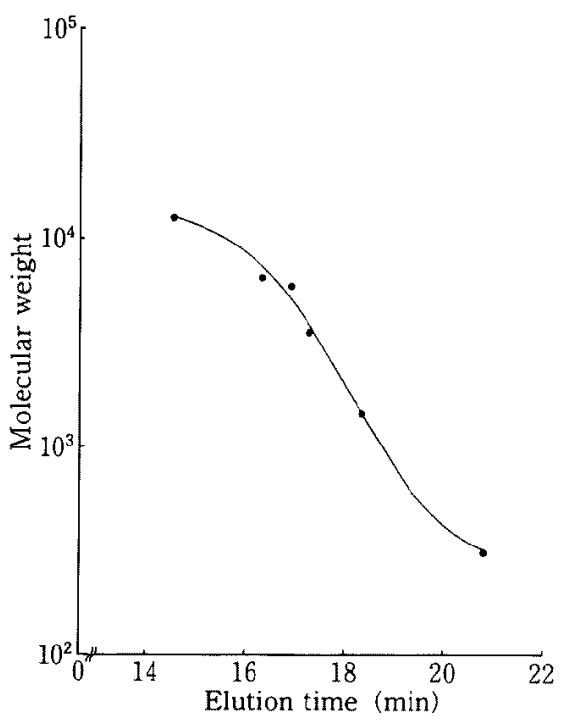

Fig. 5. Relationship between elution time and molecular weight of standard proteins and peptides.

ペプチドの分子量の分布状態は，各試験区に美はなく， 経時的にも変化は認められなかった. したがって,ここ では代表的に図 4 に M.F.S.S. 表層部での測定結果の 一部を示して置くに留める.クロマトグラムの溶出位置 と分子量の関係は，表 4 に示す 6 種類のたんぱく質およ びペプチドを標準品として調べた（図5），熟成・乾燥 0 日 目，20日目および40日目にそれぞれ6，6および7個 のピークが認められ，これらは量的にも増加傾向を示し た。しかし，本実験の測定方法では，ピーク 3-6は分 子量 300 以下の低分子量物質であり，アミノ酸ともぺプ チドとも断定されず，また $210 \mathrm{~nm}$ の吸光值はそのま まぺプチドの量に比例するとは限らない，したがって， ここではピーク1および2について，その分子量の分布 状態だけを考察するに留めた。 それによれば，これらサ ラミンーセージ中のペプチドの分子量は，いずれの場合 においても 800 程度（ピーク2）に主ピークを示す分布 状態であった.

これらの結果から，熟成風味の重要な要素の一つであ る遊離了ミ，酸およびぺプチドの蓄積に関して，P. miczynskii の及ばす影響は少ないと考えられる。一方, 著者らは前報》で，これらの試料の細菌丵を調べ，その 結果 M.F.S.S., F.S.S. 区間とS.S. 区では菌叢が異 なり，前者が L. plantarum TF-1 株が主菌裳を占め たのに対して, 後者では表層部が Staphylococcus, 中心部が L. plantarum TF-1 株以外の乳酸菌が優勢 
沼田・冨家・水谷・橋本・山田・中村

菌種であったことを報告した。この菌丵の相違は，全遊 離アミノ酸量の経時的な違いとして現われているが，熟 成・乾焻工程を通しての遊離了ミノ酸量拉よび各遊離ア ミノ酸，アンモニア，ペプチドの消長にはいずれの区間 においてあ蝢著な差は認められず，熟成風味の生成には 関与しているよは思われなかった。これらの風味関連物 質はM.F.S.S. における熟成風味の特徵付けにはそれ
ほど影響を及ぼしていないことが示唆された。

\section{5. 遊離脂肪酸}

遊離脂肪酸の測定結果を表 5-7 に示した。全遊離脂 肪酸量の経時変化は M.F.S.S. の表層部で非常に特徴 的であり，他の試験区に比べて著しい增加が認められた。 特に 10 日目では 0 日目の 3.5 倍に達した。これは以後 20 日目まで漸增傾向を示したが，その後の変化は認められ

Table 5. Free fatty acids composition in S.S. at five stages during aging and drying process (mg/g fat)

\begin{tabular}{|c|c|c|c|c|c|c|c|c|c|}
\hline \multirow[b]{2}{*}{ fatty acids } & \multicolumn{5}{|c|}{$\begin{array}{c}\text { Surface } \\
\text { Stage of aging and drying (days) }\end{array}$} & \multicolumn{4}{|c|}{$\begin{array}{c}\text { Internal part } \\
\text { Stage of aging and drying (days) }\end{array}$} \\
\hline & 0 & 10 & 20 & 30 & 40 & 10 & 20 & 30 & 40 \\
\hline$C_{14: 0}$ & & 0.7 & 0.6 & 0.8 & 1.1 & 0.7 & 1.1 & 1.5 & 1.8 \\
\hline $\mathrm{C}_{16: 0}$ & 6.4 & 8.0 & 7.6 & 10.6 & 13.0 & 8.2 & 9.6 & 11.3 & 14.0 \\
\hline $\mathrm{C}_{16: 1}$ & 1.1 & 1.4 & 1.0 & 1.1 & 1.9 & 1.6 & 1.4 & 1.8 & 2.1 \\
\hline $\mathrm{C}_{18: 0}$ & 3.2 & 3.8 & 3.8 & 5.0 & 5.8 & 3.6 & 4.4 & 6.6 & 7.4 \\
\hline $\mathrm{C}_{18: 1}$ & 11.3 & 13.2 & 12.4 & 18.9 & 22.4 & 14.2 & 16.8 & 20.2 & 26.8 \\
\hline $\mathrm{C}_{18: 2}$ & 3.8 & 3.8 & 4.4 & 8.3 & 10.2 & 4.0 & 4.8 & 8.2 & 10.4 \\
\hline $\mathrm{C}_{18: 3}$ & & & 0.6 & 0.6 & 0.6 & & 0.7 & 0.6 & 0.8 \\
\hline \multicolumn{10}{|l|}{$\mathrm{C}_{20: 0}$} \\
\hline $\mathrm{C}_{20: 1}$ & & & 0.6 & 0.5 & 0.6 & & 0.5 & 0.6 & 0.6 \\
\hline \multicolumn{10}{|l|}{$\mathrm{C}_{20: 2}$} \\
\hline \multicolumn{10}{|l|}{$\mathrm{C}_{20: 3}$} \\
\hline $\mathrm{C}_{20: 4}$ & & 0.3 & 0.9 & 0.8 & 0.9 & 0.3 & 1.0 & 0.9 & 0.8 \\
\hline Total & 25.8 & 31.2 & 31.9 & 46.6 & 56.5 & 32.6 & 40.3 & 51.7 & 64.7 \\
\hline
\end{tabular}

Table 6. Free fatty acids composition in F.S.S. at five stages during aging and drying process (mg/g fat)

\begin{tabular}{|c|c|c|c|c|c|c|c|c|c|c|}
\hline \multirow[b]{2}{*}{ Free } & \multirow[b]{2}{*}{ fatty acids } & \multicolumn{5}{|c|}{$\begin{array}{c}\text { Surface } \\
\text { Stage of aging and drying (days) }\end{array}$} & \multicolumn{4}{|c|}{$\begin{array}{l}\text { Internal part } \\
\text { Stage of aging and drying (days) }\end{array}$} \\
\hline & & 0 & 10 & 20 & 30 & 40 & 10 & 20 & 30 & 40 \\
\hline & $C_{14: 0}$ & & 0.7 & 0.7 & 0.8 & 1.7 & 0.7 & 0.7 & 1.4 & 1.6 \\
\hline & $\mathrm{C}_{16: 0}$ & 6.4 & 7.4 & 7.0 & 10.8 & 11.5 & 7.8 & 9.2 & 10.8 & 15.2 \\
\hline & $\mathrm{C}_{16: 1}$ & 1.1 & 1.0 & 1.0 & 1.4 & 2.8 & 1.1 & 1.0 & 1.5 & 2.0 \\
\hline & $\mathrm{C}_{18: 0}$ & 3.2 & 3.7 & 4.0 & 4.4 & 5.6 & 3.8 & 4.6 & 7.6 & 7.8 \\
\hline & $\mathrm{C}_{18: 1}$ & 11.3 & 12.4 & 12.4 & 18.6 & 20.0 & 15.0 & 17.3 & 21.5 & 25.8 \\
\hline & $\mathrm{C}_{18: 2}$ & 3.8 & 4.7 & 2.0 & 2.5 & 9.3 & 5.2 & 7.3 & 9.0 & 9.8 \\
\hline & $\mathrm{C}_{18: 3}$ & & & 0.3 & & 0.8 & & 0.3 & 0.2 & 0.7 \\
\hline \multicolumn{11}{|c|}{$\mathrm{C}_{20: 0}$} \\
\hline & $\mathrm{C}_{20: 1}$ & & & 0.6 & 0.6 & 0.5 & & 0.3 & 0.6 & 0.6 \\
\hline \multicolumn{11}{|c|}{$\mathrm{C}_{20: 2}$} \\
\hline \multicolumn{11}{|c|}{$\mathrm{C}_{20: 3}$} \\
\hline & $\mathrm{C}_{20: 4}$ & & 0.3 & 0.6 & 0.6 & 1.0 & 0.3 & 0.6 & 0.6 & 0.7 \\
\hline & Total & 25.8 & 30.2 & 33.6 & 44.7 & 53.2 & 33.9 & 41.3 & 53.2 & 64.2 \\
\hline
\end{tabular}


Table 7. Free fatty acids composition in M.F.S.S. at six stages during aging and drying process ( $\mathrm{mg} / \mathrm{g}$ fat)

\begin{tabular}{|c|c|c|c|c|c|c|c|c|c|c|c|}
\hline \multirow[b]{2}{*}{ Free fatty acids } & \multicolumn{6}{|c|}{$\begin{array}{l}\text { Surface } \\
\text { Stage of aging and drying (days) }\end{array}$} & \multicolumn{5}{|c|}{$\begin{array}{l}\text { Internal part } \\
\text { Stage of aging and drying (days) }\end{array}$} \\
\hline & 0 & 10 & 20 & 30 & 40 & 50 & 10 & 20 & 30 & 40 & 50 \\
\hline $\mathrm{C}_{14: 0}$ & & 1.3 & 1.7 & 1.3 & 1.4 & 1,7 & 0.6 & 1.0 & 1.4 & 1.7 & 1.8 \\
\hline$C_{16: 0}$ & 6.4 & 18.5 & 26.3 & 20.3 & 25.8 & 27.2 & 7.6 & 9.2 & 10.3 & 12.0 & 14.6 \\
\hline$C_{16: 1}$ & 1.1 & 3.0 & 4.0 & 3.0 & 3.9 & 4.1 & 1.2 & 1.0 & 1.4 & 1.7 & 2.0 \\
\hline$C_{18: 0}$ & 3.2 & 7,4 & 10.8 & 8.9 & 10.8 & 10.8 & 3.4 & 4.6 & 6.2 & 6.9 & 7.4 \\
\hline$C_{18: 1}$ & 11.3 & 44.8 & 51.8 & 43.3 & 48.7 & 50.3 & 13.8 & 16.1 & 19.3 & 25.4 & 26.0 \\
\hline$C_{18: 2}$ & 3.8 & 13.8 & 17.5 & 13.2 & 15.9 & 18.1 & 4.0 & 4.5 & 7.8 & 10.3 & 10.4 \\
\hline$C_{18: 3}$ & & 0.7 & 1.3 & 0.8 & 1.4 & 1.6 & & 0.3 & 0.5 & 0.3 & 0.5 \\
\hline \multicolumn{12}{|l|}{$\mathrm{C}_{20: 0}$} \\
\hline $\mathrm{C}_{20: 1}$ & & 1.0 & 1.3 & 1.0 & 1.2 & 1.2 & & 0.5 & 0.6 & 0.3 & 0.5 \\
\hline $\mathrm{C}_{20: 2}$ & & 0.7 & 0.6 & 0.5 & 0.5 & 0.6 & & & & & \\
\hline \multicolumn{12}{|l|}{$\mathrm{C}_{20: 3}$} \\
\hline $\mathrm{C}_{20: 4}$ & & 0.7 & 1.7 & 1.0 & 0.7 & 1.2 & 0.3 & 0.6 & 0.6 & 0.7 & 0.8 \\
\hline Total & 25.8 & 91.9 & 117.0 & 93.6 & 110.3 & 1.16 .8 & 30.9 & 37.8 & 48.1 & 59.3 & 64.0 \\
\hline
\end{tabular}

なかった。なお，各遊離脂肪酸の中では $\mathrm{C}_{16: 0}$ および $\mathrm{C}_{18: 1}$ の增加が顕著であった。一方, S.S., F.S.S. お よびM.F.S.S. の中心部での增加傾向には差は認められ ず，いずれも徐々に堌加して，40日目に0日目の約 2 倍となった，また，すべての試験区において遊離脂肪酸 の組成には差は認められなかった。

前報2)で著者らは, M.F.S.S. の表層部における $P$. miczynskii の菌数を調心，同菌数が熟成・乾燥初期の 10 日目までに 2 桁以上の急激な增加を示し，その後 25 日 目まで渐增したが，25日目以降は菌数に变化がないこ とを報告した．更に，熟成風味の重要な一因をなす芳香 成分について実施した官能試験の結果，カビ発酵サラミ ソーセージ特有の芳香を M.F.S.S. の表層部だけに認 めた．経時的にはその芳香は 10 日目より観察されて，15 日目には更に顕著なむのとなったが，その後は変化しな いことす併せて報告した。これらの結果上，本報告にお ける遊離脂肪酸量の経時变化の間には強い相関性が認め られる。それゆえ，この M.F.S.S.の表層部における 著しい遊離脂肪酸の增加は，P. miczynskii の産生す るリパーゼが関与していると思われる。ただし，本奏験 の結果ではそのリパーゼ活性は同菌の増殖期において著 しく，その後次第に低下するもの之考元られる。この現 象は, カテプシンと同样にP. miczynskii のリパーゼ 活性も食塩濃度に依存して㧍り，乾燥の進行に従ってそ の活性方低下する汃らにほかならないものと推定される。 また，前報2゙で M.F.S.S.の表層部だけに熟めた特有
の芳香成分として，これらの遊離脂肪酸が重要であるこ とは，その芳香の強さが遊離脂肪酸の蓄積量に比例して いることからあ明らかであるが，一万では，M.F.S.S. の表層部を含めたいずれの試験区においても遊離脂肪酸 組成には顕著な差が認められないことから，M.F.S.S. の表層部ではこれら中鎖の遊離脂肪酸以外にも今回測定 の対象としなかった低級の遊離脂肪酸またはそれらの分 解物が P. miczynskii の作用亡して生成されているの ではないかと考えられる。

これらを総合すると，このM.F.S.S.におおる熟成 風味の発現機構には表層部之中心部でそれぞれ異なる 2 つのパターンがあると考えられる。すすなわち，中心部で のパターンはカビ発醉老伴わないサラミンーセージの場 合と同じであり，遊離アミノ酸、ペプチド，核酸関連物 質，有機酸，遊離脂肪酸またはこれらの分解物の蓄積が その風味生成に関与している，本報告に杉ける M.F.S.S. 表層部以外ての遊離アミノ酸およびアンモ二アの增加傾 向は明らかにこのことを示唆していると思われる。一方， 表層部ではこれらの風味関運物質の蓄積とともに，P． miczynskii に上る強い脂肪の分解が起こり，遊離脂肪 酸の著しい蓄積およでその分解物に由来する独特の芳香 成分を含む熟成風味か形成されている，そして，この M. F.S.S.の熟成風味はこれらの表層部と中心部の異なる 熟成風昧がうまく調和して特徴付けられているすのと推 定される。

な抢，これらの熟成風味に㧍いては，特に呈味性の観 


\section{沼田・富家・水谷・橋本・山田・中村}

点からみた場合の核酸関連物質および有機酸の消長も重 要であると思われる. DIERICKら はドラインーセー ジの熟成中において，総ヌクレオチド量の隇少と総邓ク レオシド量の增加を明らかにし，それが乳酸菌スタータ 一カルチャーの存在の有無に影隌されないことを報告し ている. 本報告では核酸関連物質および有機酸の消長に ついては解明し得なかったが, P. miczynskii がこれ らの物質の消長に及ぼす影響は非常に興味深いものがあ りここれは今後の検討課題にしたいと考える.

終りにご校閲を睗った日本食肉生産技術総合センター 会長矢野幸男博士ならびに発表を許可された伊藤八ム株 式会社専務取締役伊藤協治氏に深謝いたします。

\section{文献}

1）中村豊郎 - 沼田正寛・橋本小由利，日畜会報，56： 938-946. 1985 .

2）沼田正寛・富家崇弘・橋本小由利・中村豊郎，日 畜会報，59：12-22。1988。

3) Glolitti, G., C.A. Cantoni, M.A. Blanchi and P. Renson, J. Appl. Bacteriol., 34: 51-56. 1971.

4) Dierick. E., P. Vandekerckhove and D. DemeYer, J. Food Sci., 39 : 301-304. 1974.

5) Melo, T.S., T.N. Blumer and H.E. SwaISGOD, J. Food Sci., 39 : 511-515. 1974.

6) Eilberg, B.L. and H.U. Liepe, Fleis- chwirtschaft, $57:$ 1687-1690. 1977.

7）厚生省環境衛生局監修，食品衛生検查指針（I）, 18-19. 日本食品衛生協会. 1973.

8）厚生省環境衛生局監修，食品衛生検査指針（I）. 23-24. 日本食品衛生協会. 1973.

9）厚生省環境衛生局監修，食品衞生検査指針（I）. 38-39. 日本食品衛生協会. 1973 .

10）沖谷明紘・西村敏英・金子成延・千々岩壬・加藤 博通，日畜会報，57：593-600. 1986.

11）菅原 潔 - 副島正美, 蛋白質の定量法 第 2 版。 39-46. 学会出版センター. 東京. 1977.

12) Folch, J., M. LeEs and G.H.S. StAnLEY, J. Biol. Chem., 226 : 497-509. 1957.

13) McCarthy, R.D. and A.H. Duthie, J. Lipid Res., 3 : 117-122. 1962.

14）日本油化学協会編，基準油脂分析試験法．2-77. 1977.

15) Ewan, R.C., D.G. Topel and K. ONo, J. Food Sci., 44 : 678-680. 1979.

16) Bowers, J.A., J. Agr. Food Chem., 17 : 902-903. 1969.

17) Lakritz, L., A.M. Spinelli and A.E. Wasserman, J. Food Sci., 41: 879-881. 1976.

18) Reddi, P.K., S.M. Constantinides and H.A. Dymsza, J. Food Sci., 37 : 643-645. 1972.

19) Deng, J.C. and D.A. Lilllard, J. Food Sci., 38 : 299-304. 1973. 


\title{
Changes in Flavor Related Components in Mold-fermented Salami Sausage during Aging and Drying Process
}

\author{
Masahiro Numata, Takahiro Fuke, \\ Yoshihiko Suitani, Sayuri Hashimoto, \\ Hiroyuki Yamada and Toyoo Nakamura
}

Central Research Institute, Itoham Foods Inc. Meguro-ku 153

Three types of salami sausages prepared with Penicillium miczynskii and Lactobacillus plantarum strain TF-1 (M.F.S.S.), with L. plantarum strain TF-1 only (F.S.S.) as starter cultures and with no starter culture (S.S.) were used to study the production of distinctive flavor and aroma characteristics of M.F.S.S. Chemical changes in M.F.S.S. by fungal reactions during aging and drying process were investigated as compared with those in F.S.S. and S.S.

The results obtained can be summerized as follows.

1) The major constituents of free amino acids in the initial samples were Tau, Gln, Ala and Gly. Amounts of free amino acids in M.F.S.S. and F.S.S. linearly increased during aging and drying process whereas those in S.S. increased until the 20th day and slightly decreased thereafter. The major free amino acids responsible for this increase were Glu, Leu, Lys and Ala in all samples.

2) There were no significant differences among S.S., F.S.S. and M.F.S.S. in the change of ammonia contents.

3) The contents of free amino acids and ammonia in the internal part of samples generally tended to be higher than those in the surface of samples.

4) HPLC showed that only one peak of peptide was found in all samples and its molecular weights were ca. 800 daltons. No change of HPLC pattern during aging and drying process was observed.

5) Amount of free fatty acids in the surface of M.F.S.S. remarkably increased as compared with other samples. This change of M.F.S.S. surface was very rapid in the first 10 days, slowly in 10 days after that and was not observed later. The major free fatty acids responsible for this increase were $\mathrm{C}_{16: 0}$ and $\mathrm{C}_{18: 1}$. However no significant difference among all samples existed in the constituents of free fatty acids.

$$
\text { Jpn. J. Zootech. Sci, } 59 \text { (2) : 136-145, } 1988
$$

Key words : salami sausage, mold fermentation, Penicillium, cured meat flavor, free fatty acid 